\title{
Urban Rejuvenation through Techno Art Intervention: A case of Kolkata
}

\author{
Tanima Bhattacharya \\ RCGSIDM \\ Indian Institute of Technology \\ Kharagpur \\ Kharagpur, India \\ Tani.bhattacharya1@gmail.com
}

\author{
Dr.Ankhi Banerjee \\ RCGSIDM \\ Indian Institute of Technology \\ Kharagpur \\ Kharagpur, India
}

\author{
Prof. Joy Sen \\ RCGSIDM, ARP \\ Indian Institute of Technology \\ Kharagpur \\ Kharagpur, India
}

\begin{abstract}
The images of urban spaces, at present, are manifesting dystopic imageries that are obstructing for the functioning of the public realm. Habitable space of a city should be shaped according to human purposes and to satisfy their needs. In defining urban space design, urban nodes acted as nuclei to provide access and opportunity to the people. Nodes generate out of physical traits, activities and are supported by physical spatial design and public interaction. The scale of nodes varies from large urban squares to a small park, to a partially enclosed space in front of a building, to a sidewalk. Since the cores of the cities are generally highly congested and promoted multi-layered activities, Nodes can be presented strategically to get perceptual importance. Imageability of all these spaces is dependent on the quality attributed to the physical presentation of a space that induces high probability of evoking strong images in the mind of the observer. Thus, rejuvenation of these urban nodes can act as an intervening process to regenerate habitable breathing space amongst the dystopic condition of the city.
\end{abstract}

With analysis of the existing scenario of these nodes, the elements for techno-art intervention to alter the physical, tangible imageability of the nodes can possibly be identified. Thus, the paper explores the present rate of imageability of the nodes and what could be the possible art and design solutions based on the expert's opinion to intervene for the betterment of the experience of the physical space.

Keywords- techno-art intervention; space rejuvenation; imageability; space design; urban nodes

\section{INTRODUCTION}

"As an artificial world, the city should be so in the best sense: made by art, shaped for human purposes" [1]

Kevin Lynch

The study of techno art based design implementation to alter the physical tangible traits of the urban nodes can be started with broad investigation of the different aspects and possibilities of techno art solutions. Assessment of the present situation of the urban nodes is intriguing once activity-based design alterations of urban spaces is taken into consideration. The different tools for activity based alteration of urban spaces as well as visual augmentation are street art, art installations, craftivism, gardening, graffiti, performance art, participatory events for children and community, socio-cultural events such as festivals, reclaim the streets, etc [2].
Advocating that urban design is "a temporal form of art" [3] (Lynch; 1960), assessing the legibility of spaces and their key components, potential for rejuvenation and mode of alteration, is focus of the paper. The visual quality of environment or imageability [4] serves a distinct purpose of assigning its character and locational attractiveness quotient. On one hand, imageability depend on the demographical, physical and design attributes of space, namely, landuse, type of built environment, patterns formed by roads and building blocks, and socio-economic characteristics, which is tangible. On the other, imageability is imprinted by the emotional attachment with particular spaces based on socio-cultural norms, traditions and individual experiences, which is intangible. An understanding of the tangible and intangible elements associated with imageability of space is necessary to bring about any change to achieve the goal of rejuvenation of urban space.

Impact of technological changes have caused paradigm shifts in human behaviour and as the world is shrinking due to „Globalization" the distance between humans is increasing, human interactions and humanity is gradually losing its shine. A major aspect of all great civilization has been facilitating human interaction in organized public spaces. Reclamation of the public realm has a social purpose and rejuvenation of urban spaces is a mean of ensuring increased human interaction. The paper attempts to frame a methodology for identifying element of design components to facilitate rejuvenation of existing urban space inclusive of hard and soft infrastructure.

The study objectives are,

- Evaluation of the existing situation of urban areas based on imageability

- Identification of elements/channels for rejuvenation of the urban areas

\section{LITERATURE REVIEW}

Alike the huge body of discourse on urban planning and design solutions are available and had explored earlier, 
experiment and implementation of techno art solution in solving the social infrastructural issues not received much exploration. A substantial body of popular discourses on the various individual phenomena related to histories and surveys from respected art and design publishers (especially on street art, e.g., Chalfant and Prigoff 1987; Ganz 2004; Manco 2004; but also of interventionist art more generally, that acclaims critical appreciation from contemporary and successive pedagogues, such as Lacy 1995; Seno 2010); radical, individualistic or independent accounts of particular interventionist actions (e.g., Bloom and Bromberg 2004; Wilson and Weinberg 1999); "manifestos" and other publications by interventionists themselves as can be seen in different art movements (e.g., Fairey 1990; Moore and Prain 2009; Reynolds 2004); Urban Design and planning (A. H. Whittemore); Ecological urbanism etc. have been documented [5].

In academics related to social science, there are relatively few focused studies on imageability alteration of urban spaces by altering art and design approach. Among the existed part of literature, the basic field of practices are dealing with urban design studies, urban regeneration process and pattern. There was a very little body of work to showcase the connection between art, design, community activities and participation [6], that would further address the question of appearance and imageability of a particular space. The perspective of using art and design as an indispensable part of traditional urban planning considers a variety of practices with its grounding. It used as a process essentially to accommodate the exponentially growing urban sprawl, and frequently seems to imply that these acts have little deeper significance beyond serving as an indicator of liveability of the spaces.

Imageability is the "quality in a physical object which gives it a high probability of evoking a strong image in any given observer" [7]. Physical structural visibility of a space or of an object provokes behavioural approach amongst the stakeholders. The study of imageability is expressly interested in "the need for identity and structure in our perceptual world, and to illustrate the special relevance of this quality to the particular case of the complex, shifting urban environment" [8]. The researcher believes a human being can create their environment"s image by operation on the external physical shape as well as internally.

Likewise, urban nodes can be designed specifically to enhance public interaction and activity. For example, paths, which generally structure the city, can be designed with/for visual hierarchies, clarity of direction, differentiated, kinesthetic, etc. We can make an imageable landscape is that is "visible, coherent, and clear" (Lynch, 91). The nodes can act as a point of public speculation, therefore the city should be so in the best sense: "made by art, shaped for human purposes" (Lynch, 95).

"A highly developed art of urban design is linked to the creation of a critical and attentive audience. If art and audience grow together, then our cities will be a source of daily enjoyment to millions of their inhabitants" (Lynch; 120)

\section{METHODOLOGY}

The study aims to analyze urban nodes based on

1. existing urban spaces based on its imageability
2. Assessing the potential for rejuvenation through techno-art intervention.

To analyze the situational elements of urban spaces, a group of twenty urban spaces have been identified in and around Kolkata Municipal Corporation (KMC), which is the core of the Kolkata Urban Agglomeration - one of the most populous metropolitan area in the world. KMC is chosen as a case study for putting forward a methodogical framework for rejuvenation of urban space based on imageability. Six locations have been identified in the KMC in this study for ease of analysis.

This section provides a brief description of Kolkata Municipal Corporation (KMC) along with identification of six spots within the KMC for detailed analysis. A questionnaire survey was conducted among 15 experts for recording their opinion about the six identified locations based on physical attributes, emotional attributes and potential for intervention on a Likert scale. Analysis of obtained data provides evaluation of existing locational attractiveness and identification of elements for rejuvenation and potential means of intervention.

Kolkata Municipal Corporation represents the core city of Kolkata, the largest city in Eastern India. KMC consists of 141 wards, covers an area of 185 sq. Km., with 4.48 million population (approximately) and population density of 24000 persons / sq. Km. The six locations as identified for the study are well known activity centres and majority of the urban dwellers have visited these locations and are well informed about them to offer opinions. Fig. 1 shows the identified locations within KMC.

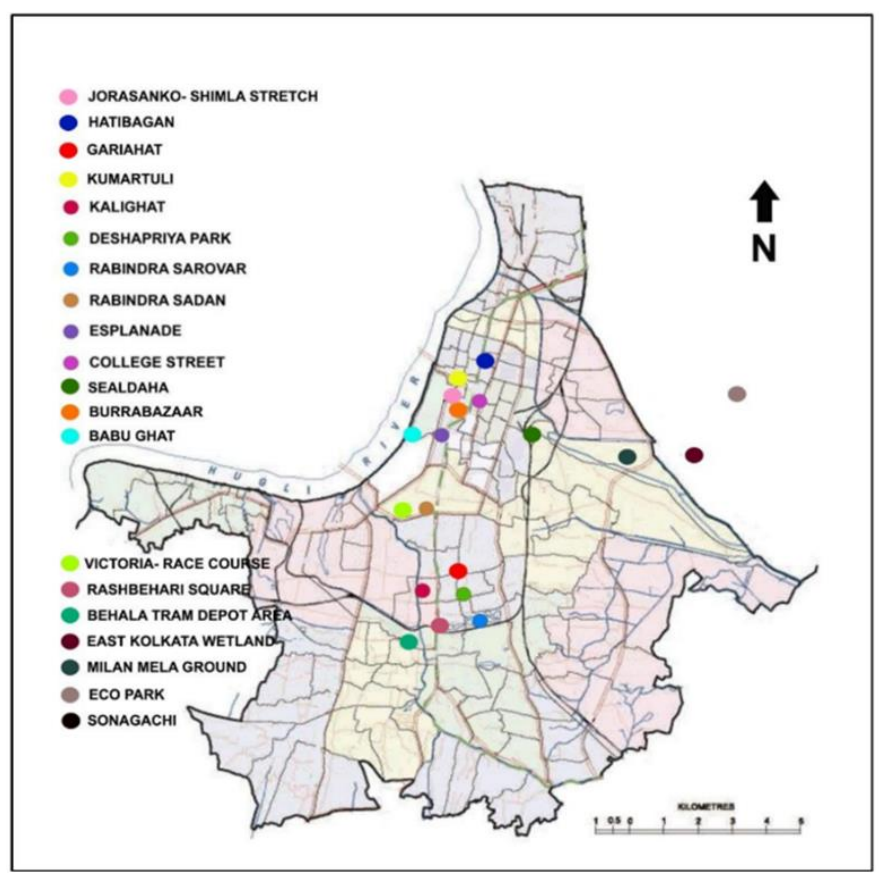

Figure 1. Location map of KMC with identified twenty urban spaces

\section{A. Identification of the Urban Nodes}

Based on the landuse, population density, activity concentration of majority of the stakeholders, different types of urban nodes can be identified, namely, commercial zones, 
manufacturing zones, administrative areas, industrial areas, business districts, ecologically sensitive areas, religious areas, recreational areas, transit oriented urban nodes, residential areas, areas popularized based on creative economy, educational hub etc. Different types of urban spaces exemplify different set of challenges regarding its imageability. In this paper, to best explore the possibility of urban space/nodes rejuvenation twenty urban areas have been selected based on their land-use and activity pattern across the city to address the study objectives and propose solutions catering to varied way of space utilization. Study of these spaces would help to understand the character and the dynamics of city spaces. Individual spaces aided individual components to the overall imageability of the city.

Identified twenty urban spaces can possibly be grouped based on the landuse pattern and usability to locate space dynamics and predominant place making pattern. Specified urban spaces have been exhaustively documented and analyzed to bring out the present imageability and its scope for future rejuvenation based on technology and art alternatives.

The identifies study areas are,

1. Kalighat (traditional religion-centric nodes),

2. Deshapriya Park (majorly residential and transit area),

3. Rabindra Sarovar (Ecologically sensitive green open land and water body),

4. Rabindra sadan (major cultural centre),

5. Esplanade (Economy driven urban node),

6. College Street (Intellectual hub of Kolkata)

7. Jorasanko-Shimla stretch (Heritage and major commercial area)

8. Hatibagan (Commercial and transport based development)

9. Gariahaat (Commercial and residential)

10. Kumartuli (Creative economy and residential)

11. Sealdaha (prime transportation location and commercial)

12. Burrabazaar (Commercial area)

13. Babu Ghat (Recreational and heritage area)

14. Victoria-Race course area (Heritage and recreational)

15. Rashbehari square (Transportation and residential)

16. Behala tram depot (Transportation and residential)

17. East Kolkata Wetland (Eco-sensitive, Commercial area)

18. Milan mela ground (Recreational)

19. Eco park (Recreational)

20. Sonagachi area (Commercial and residential)

Above mentioned spaces were mapped to point out their physical attributes, based on which a visual SWOT (through reconnaissance survey) can be done to pinpoint the commonalities to group these places. After analysing the existing imageability of these spaces, the potentiality of alteration by implementing technical art and design has been calculated.

Fig 2 to fig. 15 presents a detailed location map of twenty identified urban locations while Table 1 provides a brief description about them.
TABLE I.

COMPARISON BETWEEN IDENTIFIED LOCATIONS BASED ON ACTIVITY PATTERNS

\begin{tabular}{|c|c|c|c|}
\hline Location & Description & Major & Major activity \\
\hline & & Landuse & patterns \\
\hline Kalighat & $\begin{array}{l}\text { Kalighat area is famous } \\
\text { for The Kali temple } \\
\text { complex situated on the } \\
\text { eastern bank of } \\
\text { previous flow path of } \\
\text { river Ganga, which is } \\
\text { sacred for Hindus. The } \\
\text { spiritual precinct might } \\
\text { have a connection with } \\
\text { the name of the city } \\
\text { Kolkata. }\end{array}$ & $\begin{array}{l}\text { Religious, } \\
\text { Residential } \\
\text { Commercial }\end{array}$ & $\begin{array}{l}\text { It is a busy hub of } \\
\text { Religious activity } \\
\text { throughout the year. It } \\
\text { is also a major hub of } \\
\text { creative } \\
\text { craftsmanship, } \\
\text { particularly, Pata } \\
\text { paintinge. }\end{array}$ \\
\hline $\begin{array}{l}\text { Deshapriya } \\
\text { Park }\end{array}$ & $\begin{array}{l}\text { An important open } \\
\text { space beside an arterial } \\
\text { Road- Rashbehari } \\
\text { Avenue, well-known } \\
\text { for community } \\
\text { interaction and } \\
\text { participation. }\end{array}$ & $\begin{array}{l}\text { Residential, } \\
\text { Commercial }\end{array}$ & $\begin{array}{l}\text { The green area set } \\
\text { amidst low-rise (4- } 6 \\
\text { storied buildings) } \\
\text { buildings having } \\
\text { mixed use- } \\
\text { commercial activity } \\
\text { offers a must needed } \\
\text { breathing space. }\end{array}$ \\
\hline $\begin{array}{l}\text { Rabindra } \\
\text { Sarovar }\end{array}$ & $\begin{array}{l}\text { Planned green space, } \\
\text { developed in } 1920 . \\
\text { Area includes a huge } \\
\text { water body, rowing } \\
\text { clubs, park, and } \\
\text { playground. }\end{array}$ & $\begin{array}{l}\text { Recreational, } \\
\text { Residential }\end{array}$ & $\begin{array}{l}\text { People utilize the } \\
\text { place throughout the } \\
\text { year for different } \\
\text { activities. }\end{array}$ \\
\hline $\begin{array}{l}\text { Rabindra } \\
\text { Sadan }\end{array}$ & $\begin{array}{l}\text { The area houses } \\
\text { auditoriums, } \\
\text { exhibition space, } \\
\text { movie screens among } \\
\text { other centres. }\end{array}$ & Recreational & $\begin{array}{l}\text { Major hub for Art } \\
\text { and culture. }\end{array}$ \\
\hline Esplanade & $\begin{array}{l}\text { Esplanade is one of } \\
\text { the prime commercial } \\
\text { zones of Kolkata as } \\
\text { well as an important } \\
\text { transportation node. }\end{array}$ & $\begin{array}{l}\text { Commercial, } \\
\text { Transportation }\end{array}$ & $\begin{array}{l}\text { Receive highest } \\
\text { footfall amongst } \\
\text { all the commercial } \\
\text { economy based } \\
\text { zones in Kolkata }\end{array}$ \\
\hline $\begin{array}{l}\text { College } \\
\text { Street }\end{array}$ & $\begin{array}{l}\text { Recognized centre of } \\
\text { intellectual activity. } \\
\text { Houses many } \\
\text { colleges, schools over } \\
100 \text { years old. }\end{array}$ & $\begin{array}{l}\text { Education, } \\
\text { Commercial, } \\
\text { Health }\end{array}$ & $\begin{array}{l}\text { The place acts as the } \\
\text { hub of Education. } \\
\text { Presence of the } \\
\text { largest book market } \\
\text { in Kolkata. }\end{array}$ \\
\hline $\begin{array}{l}\text { Jorasanko- } \\
\text { Shimla }\end{array}$ & $\begin{array}{l}\text { Housed heritage sites } \\
\text { as famous Tagore } \\
\text { house and birthplace of } \\
\text { another renaissance } \\
\text { person Swami } \\
\text { Vivekananda }\end{array}$ & $\begin{array}{l}\text { Heritage, } \\
\text { residential and } \\
\text { commercial area }\end{array}$ & $\begin{array}{l}\text { The place acted as an } \\
\text { important node in } \\
\text { renaissance of } \\
\text { Bengal, now buzzing } \\
\text { with commercial } \\
\text { activities }\end{array}$ \\
\hline Hatibagan & $\begin{array}{l}\text { This area housed major } \\
\text { commercial activities } \\
\text { ranges from small } \\
\text { individual shops to } \\
\text { malls and brands }\end{array}$ & $\begin{array}{l}\text { Commercial, } \\
\text { residential, }\end{array}$ & $\begin{array}{l}\text { One of the oldest } \\
\text { commercial area in } \\
\text { Kolkata }\end{array}$ \\
\hline Gariahat & $\begin{array}{l}\text { Major commercial hub } \\
\text { includes brands and } \\
\text { contemporary fashion }\end{array}$ & $\begin{array}{l}\text { Commercial and } \\
\text { residential }\end{array}$ & $\begin{array}{l}\text { Almost all the day } \\
\text { throughout a year } \\
\text { gariahat is buzzing } \\
\text { with customers (18- } \\
35 \text { is the major } \\
\text { chunk) }\end{array}$ \\
\hline Kumartuli & $\begin{array}{l}\text { The biggest creative } \\
\text { economic section to } \\
\text { make clay idols }\end{array}$ & $\begin{array}{l}\text { Creative } \\
\text { economy, } \\
\text { residential }\end{array}$ & $\begin{array}{l}\text { Kumartuli is a live } \\
\text { display of studio } \\
\text { practice of the } \\
\text { creative craftsmen } \\
\text { who make clay idols. } \\
\text { It is the place that } \\
\text { supplies idols to } \\
\text { Kolkata, different } \\
\text { parts of the country } \\
\text { and beyond. }\end{array}$ \\
\hline Sealdaha & $\begin{array}{l}\text { Famous for being the } \\
\text { important node of }\end{array}$ & $\begin{array}{l}\text { Transportation } \\
\text { (major node of }\end{array}$ & $\begin{array}{l}\text { One of the busiest } \\
\text { node all through the }\end{array}$ \\
\hline
\end{tabular}




\begin{tabular}{|c|c|c|c|}
\hline & $\begin{array}{l}\text { Eastern railways, also } \\
\text { housed major } \\
\text { commercial activity } \\
\text { and the biggest } \\
\text { vegetable market of } \\
\text { Kolkata }\end{array}$ & $\begin{array}{l}\text { Easter railway), } \\
\text { commercial }\end{array}$ & $\begin{array}{l}\text { day, and received the } \\
\text { highest footfall in } \\
\text { compare to the other } \\
\text { identified spaces. }\end{array}$ \\
\hline Burrabazaar & $\begin{array}{l}\text { The biggest and the } \\
\text { nearest market place } \\
\text { between the two major } \\
\text { railway nodes, i.e. } \\
\text { Sealdaha and Howrah, } \\
\text { whole day packed with } \\
\text { commercial activities. } \\
\text { It housed one of the } \\
\text { major heart line of the } \\
\text { city that connects two } \\
\text { stations and also } \\
\text { receives highest traffic } \\
\text { pressure. }\end{array}$ & $\begin{array}{l}\text { Major } \\
\text { commercial hub }\end{array}$ & $\begin{array}{l}\text { Big and small shops } \\
\text { are buzzing with } \\
\text { customers all the day }\end{array}$ \\
\hline Babughat & $\begin{array}{l}\text { One of the oldest ghat } \\
\text { made by the British } \\
\text { officials to facilitate } \\
\text { themselves to the river } \\
\text { transportation. }\end{array}$ & $\begin{array}{l}\text { Heritage and } \\
\text { recreational area }\end{array}$ & $\begin{array}{l}\text { Important node for } \\
\text { river transportation }\end{array}$ \\
\hline $\begin{array}{l}\text { Victoria }- \\
\text { Race course } \\
\text { area }\end{array}$ & $\begin{array}{l}\text { Prime heritage area of } \\
\text { the city housed the } \\
\text { palace of Queen } \\
\text { Victoria (Victoria } \\
\text { memorial), Race course } \\
\text { and the largest } \\
\text { breathing space of the } \\
\text { city called Maidan }\end{array}$ & $\begin{array}{l}\text { Heritage and } \\
\text { recreational area }\end{array}$ & $\begin{array}{l}\text { Major attraction of } \\
\text { the city's tourism. } \\
\text { Receives highest } \\
\text { footfall during the } \\
\text { month of November } \\
\text { to February. }\end{array}$ \\
\hline Rashbehari & $\begin{array}{l}\text { Famous for kalighat } \\
\text { metro station and acted } \\
\text { as a major node of } \\
\text { public transportation }\end{array}$ & $\begin{array}{l}\text { Residential } \\
\text { Transportation }\end{array}$ & $\begin{array}{l}\text { This area is a busy } \\
\text { transportation node } \\
\text { along with quite old } \\
\text { community } \\
\text { settlement. Receives } \\
\text { highest footfall } \\
\text { during the festival of } \\
\text { Durga puja in the } \\
\text { month of October }\end{array}$ \\
\hline $\begin{array}{l}\text { Behala Tram } \\
\text { depot }\end{array}$ & $\begin{array}{l}\text { One of the oldest tram } \\
\text { depot of the city of } \\
\text { Kolkata. As the tram as } \\
\text { a medium of transport } \\
\text { is quite old, thus the } \\
\text { depot has a long history } \\
\text { ince pre-independence } \\
\text { era. }\end{array}$ & $\begin{array}{l}\text { Transportation, } \\
\text { Residential }\end{array}$ & $\begin{array}{l}\text { Majorly residential } \\
\text { area }\end{array}$ \\
\hline $\begin{array}{l}\text { East Kolkata } \\
\text { wetland }\end{array}$ & $\begin{array}{l}\text { It is the } n \text { extended } \\
\text { portion of the city } \\
\text { which used to be the } \\
\text { farthest part of greater } \\
\text { Sundarban area. Thus it } \\
\text { is filled up with } \\
\text { wetlands that are } \\
\text { usually used for fishery } \\
\text { and farming. The area } \\
\text { housed the major chunk } \\
\text { of the tanneries of } \\
\text { Kolkata. }\end{array}$ & \begin{tabular}{|l} 
Eco-sensitive \\
zone, Residential \\
Commercial \\
\\
\\
\end{tabular} & $\begin{array}{l}\text { Housed tanneries of } \\
\text { Kolkata and famous } \\
\text { for fisheries }\end{array}$ \\
\hline $\begin{array}{l}\text { Milan mela } \\
\text { ground }\end{array}$ & $\begin{array}{l}\text { A big green open space } \\
\text { generally used to } \\
\text { arrange governmental } \\
\text { and public programs. } \\
\end{array}$ & Recreational & $\begin{array}{l}\text { Major activities } \\
\text { during Book fair and } \\
\text { other programs }\end{array}$ \\
\hline Eco park & $\begin{array}{l}\text { Government sponsored } \\
\text { recreational area for } \\
\text { public }\end{array}$ & Recreational & $\begin{array}{l}\text { Receives highest } \\
\text { footfall during } \\
\text { holidays }\end{array}$ \\
\hline $\begin{array}{l}\text { Sonagachi } \\
\text { area }\end{array}$ & $\begin{array}{l}\text { The largest red light } \\
\text { zone of the city housed } \\
\text { in the Oldest pat of } \\
\text { North Kolkata }\end{array}$ & $\begin{array}{l}\text { Commercial, } \\
\text { Residential }\end{array}$ & $\begin{array}{l}\text { Housed quite a few } \\
\text { colonial architecture } \\
\text { and exemplifies } \\
\text { mixed land use } \\
\text { pattern }\end{array}$ \\
\hline
\end{tabular}

interventions for each location on a five point Likert scale where, one represents lowest score and five represents highest score. The factors comprising physical attributes are - availability of community space, water body, green open space, public utilities such as drinking water facility, toilet facilities, seating area, sidewalk, dust bins and signage.

Impact of historical precincts, local culture/tradition on ambience, and visual appeal, together forms the emotional attribute of the locations. Potential for intervention is judged through four channels - public space design (involving redesign/redevelopment of built and open spaces); public utilities (provision of drinking water facility, toilet facilities, seating area, sidewalk, dust bins and signage etc.); installation art (including wall art, surface painting, sculpture, topiary, exhibitions etc.); art performances (music, dance, street theatre etc.).

\section{Details of the selected urban spaces}

Selected twenty urban spaces are investigated in terms of elements of visual scape, patterns that help to create visual vocabulary of that particular space. Spaces are divided depending on the immediate tangible surrounding, traditional and cultural element that aided to the activity and participation of the community. Sealdaha is one of the busiest urban space of day to days life.
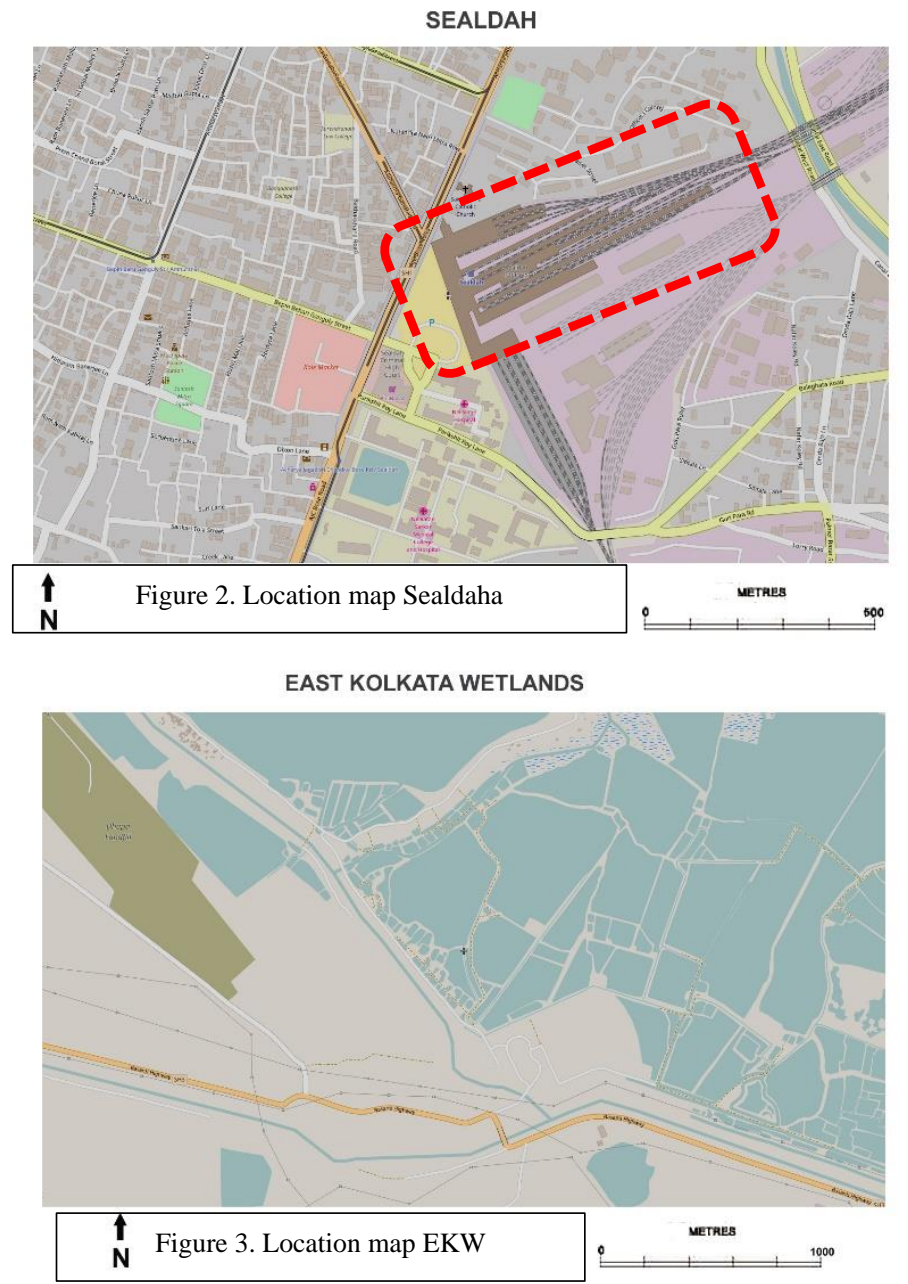

Experts were asked to given their opinion regarding physical attributes, emotional attributes and potential for 


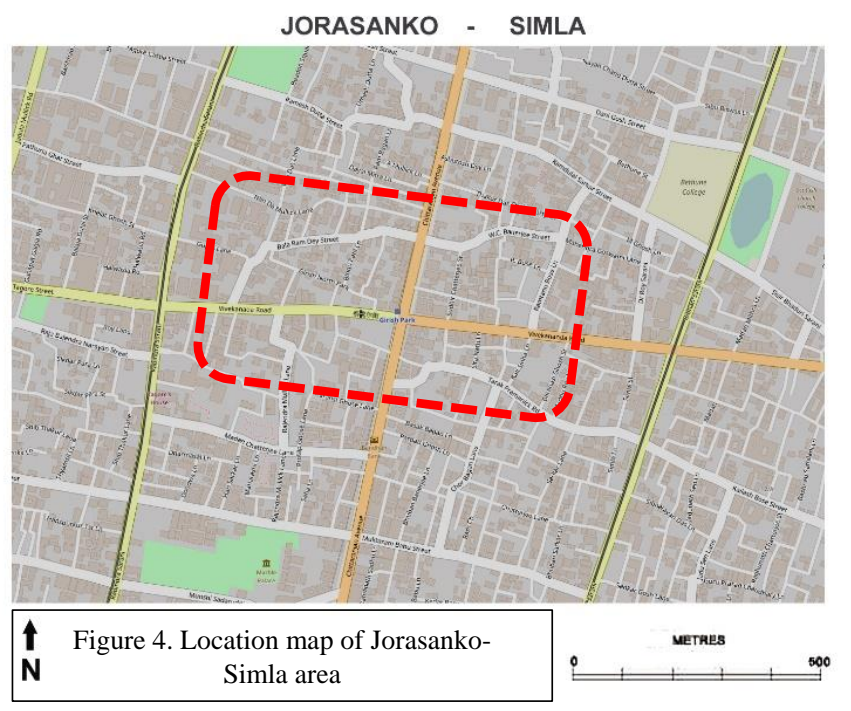

RASHBEHARI AVENUE DESHAPRIYA PARK GARIAHAT

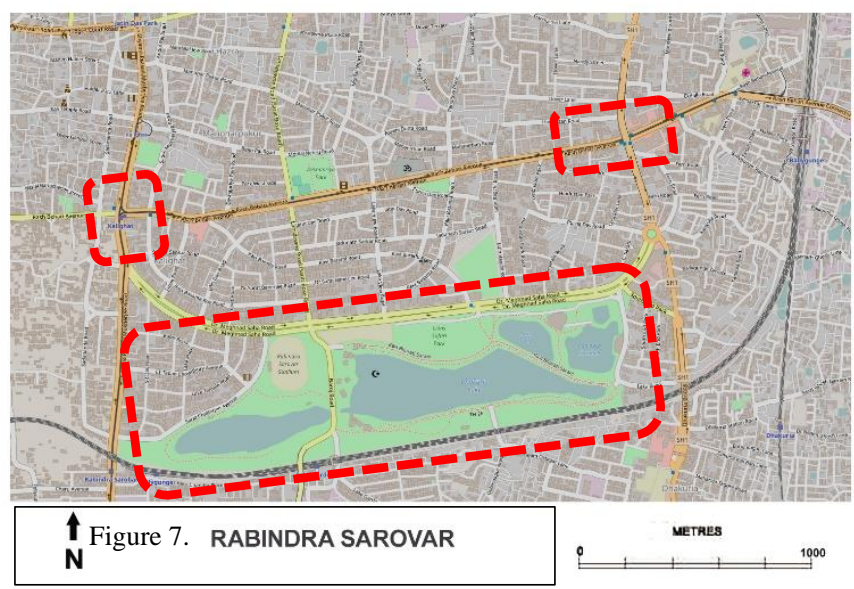

\section{BABUGHAT}

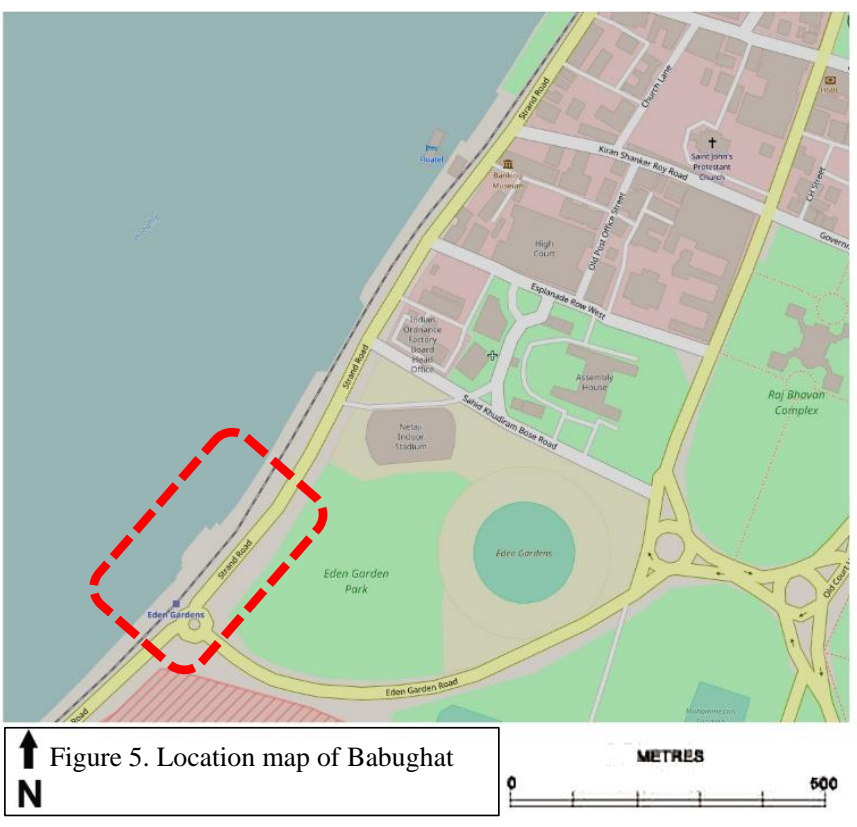

RACE COURSE-VICTORIA MEMORIAL

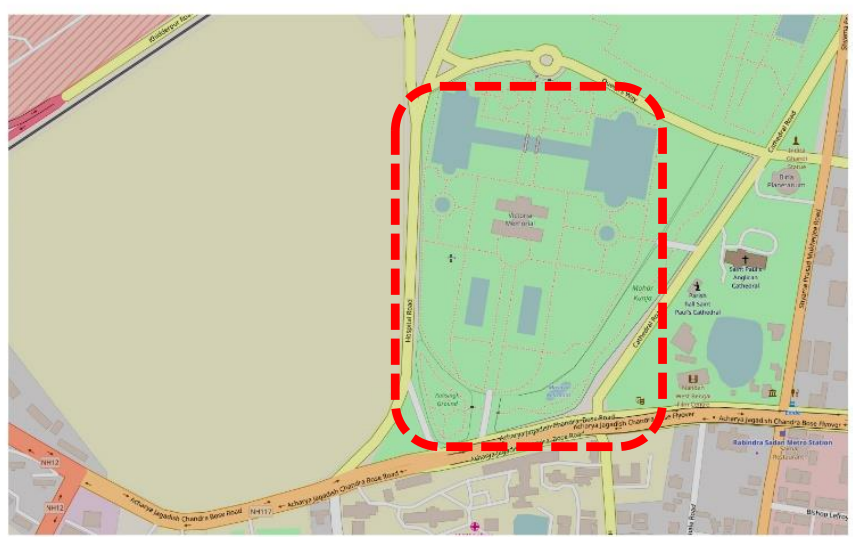

Figure 6. Location map of Rabindra sadanN Victoria and Race course

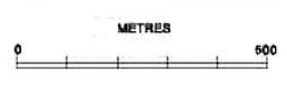

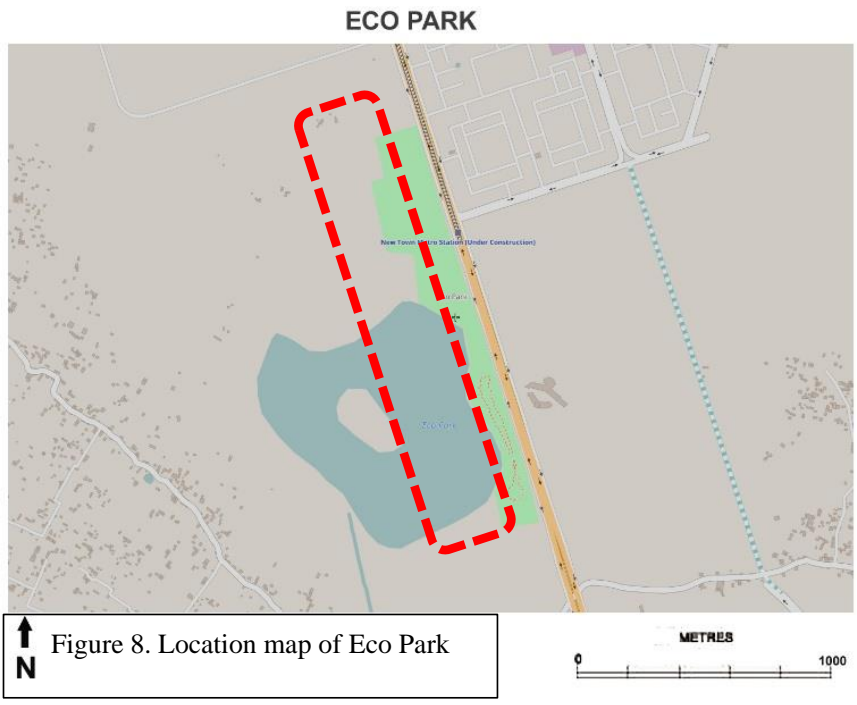

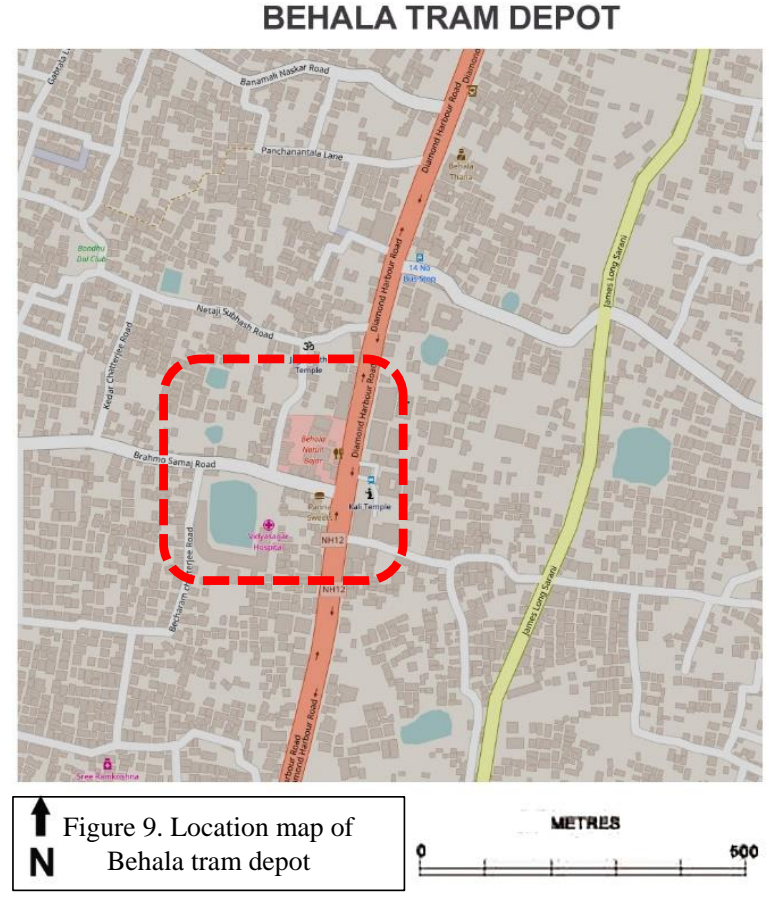


land-use pattern, namely, Residential, Recreational,

\section{KUMARTULI}

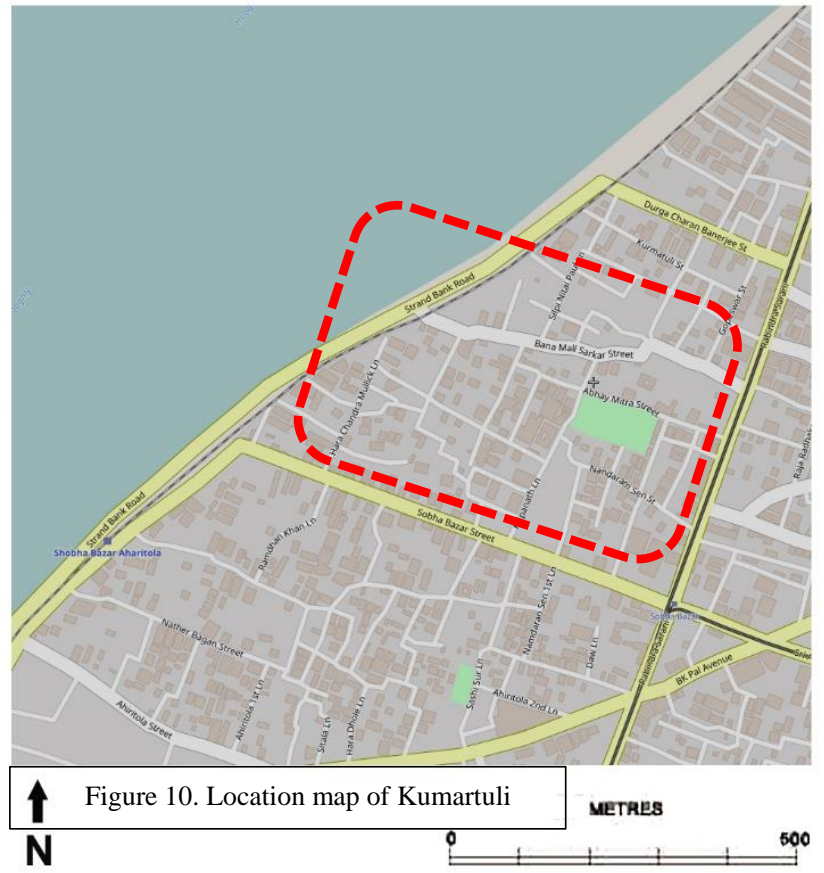

\section{Identification of the representative case studies}

Representation of the case study areas based on land use and utilization pattern. The complete study of the urban spaces of Kolkata are spread over the study of twenty urban spaces. The collected data on the current imageability of these spaces cumulatively produced the common feature or pattern of the city based on user perception and land-use. Scoring of imageability and acceptance of those spaces collectively represent the present condition of the city itself.

Presentation of the thorough study of these twenty identified urban spaces is not possible to collate in a single paper therefore, these spaces have been grouped according to their land-use pattern and utilization. One representational case study area has been selected from each group to explore the imageability and the interaction of the user with that of the urban space.

\begin{tabular}{|l|l|}
\hline Major land-use pattern & \multicolumn{1}{|c|}{ Urban spaces } \\
\hline Residential & $\begin{array}{l}\text { Deshapriya park, Jorasanko-Shimla, } \\
\text { Hatibagan, Rashbehari square, Behala } \\
\text { tram depot }\end{array}$ \\
\hline Recreational & $\begin{array}{l}\text { Rabindra sadan, Victoria-race } \\
\text { course, Babu ghat, Milan mela ground }\end{array}$ \\
\hline Transportation & $\begin{array}{l}\text { Esplanade, Sealdaha, Behala tram } \\
\text { depot }\end{array}$ \\
\hline Eco-sensitive zone & $\begin{array}{l}\text { Rabindra sarobar, Eco park, East } \\
\text { Kolkata wetland }\end{array}$ \\
\hline Commercial & $\begin{array}{l}\text { Esplanade, Burrabazaar, Sealdaha, } \\
\text { Sonagachi area, }\end{array}$ \\
\hline Heritage & $\begin{array}{l}\text { Kalighat, Babu ghat, Victoria-race } \\
\text { course, }\end{array}$ \\
\hline Educational hub & College street \\
\hline
\end{tabular}

The spaces are divided basically in the group of 7 major
Transportation, Eco-sensitive area, Commercial spaces, Heritage and cultural area and educational hub. In most of the cases these identified spaces shares two or more land-use and usability pattern. In that case the predominant coverage of the land-use and utilization purpose shall be taken for consideration in the case studies.

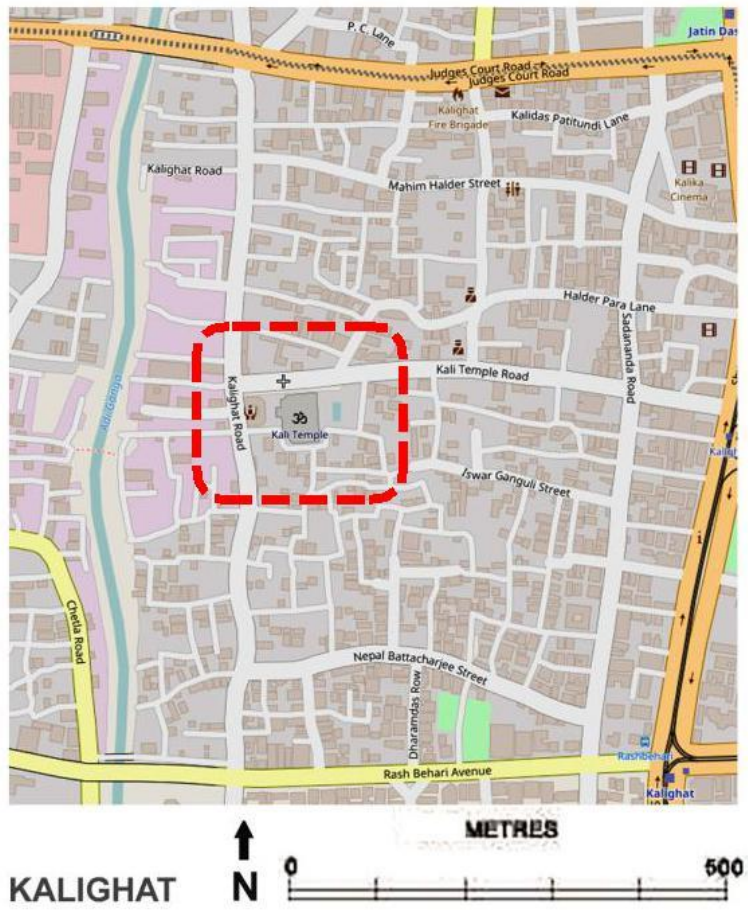

Figure 11. Location map of Kalighat

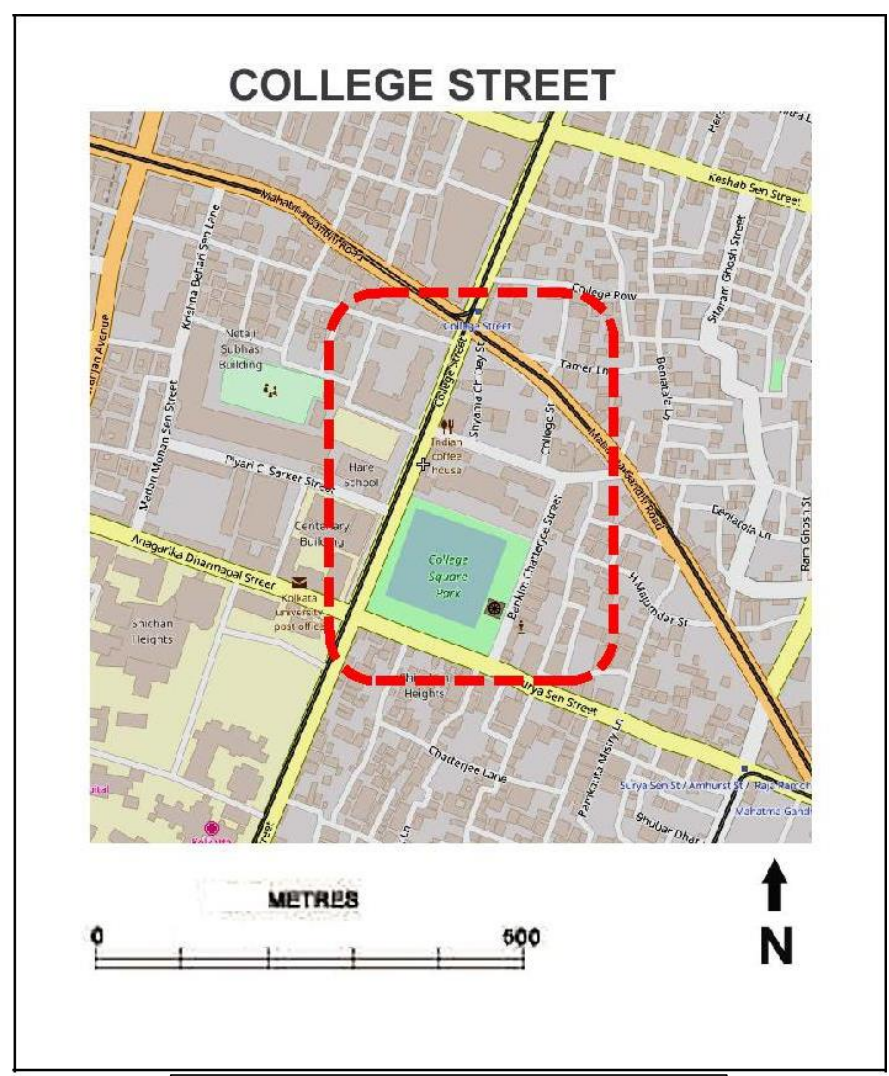

Figure 12. Location map of College Street

(C) The Author(s) 2018. This article is published with open access by the GSTF 


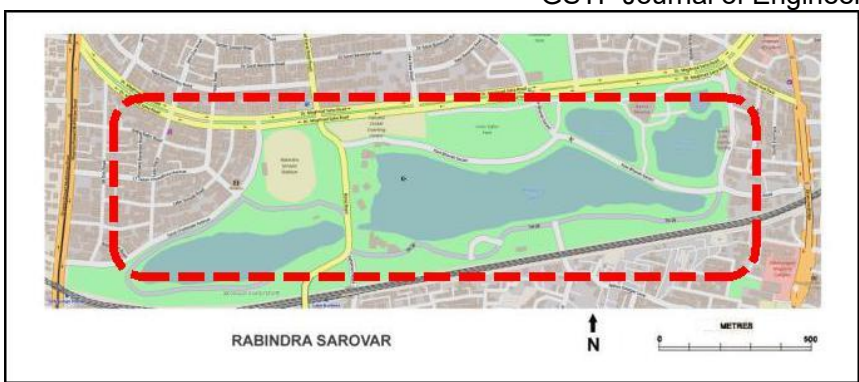

Figure 13. Location map of Rabindra Sarovar

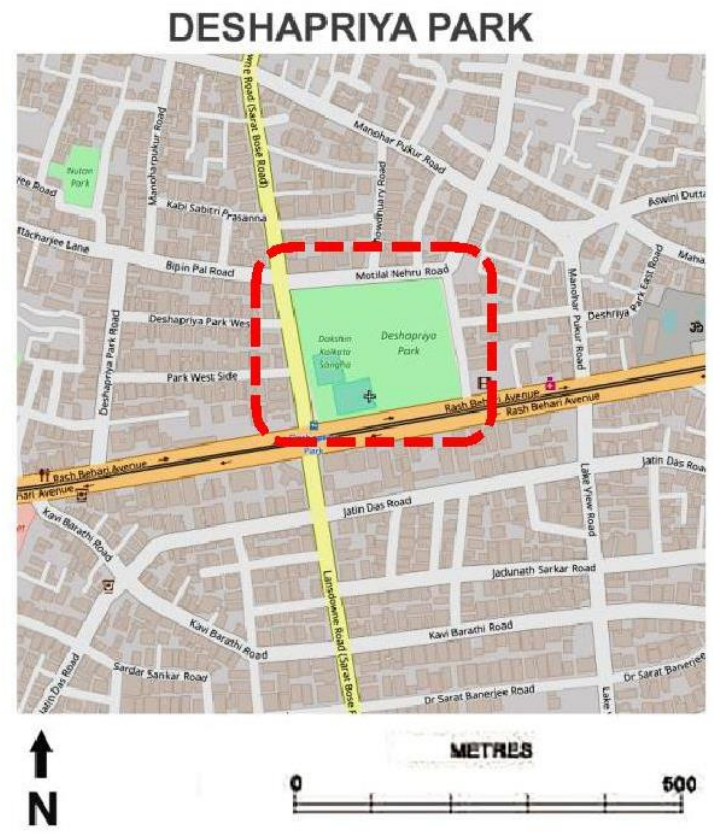

Figure 14. Location map of Deshapriya Park

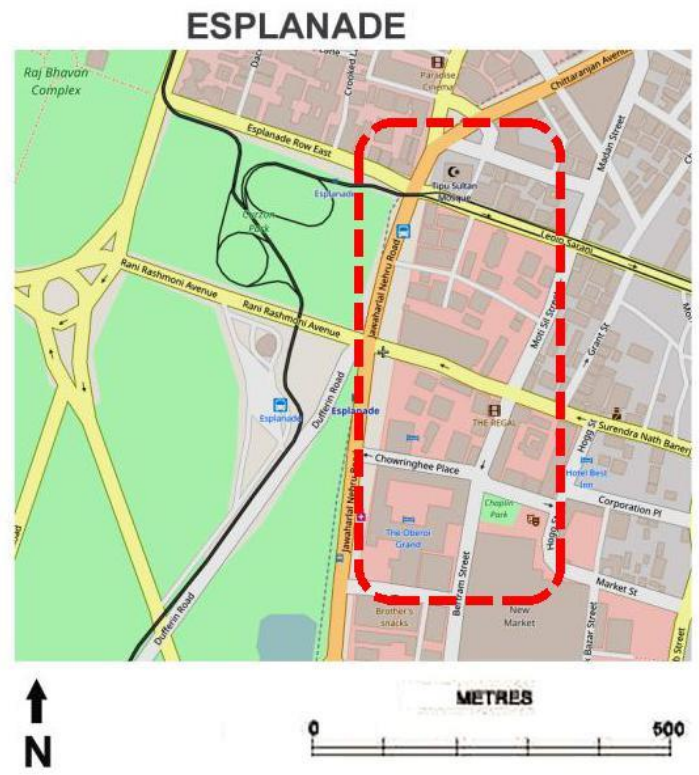

Figure 15. Location map of Esplanade

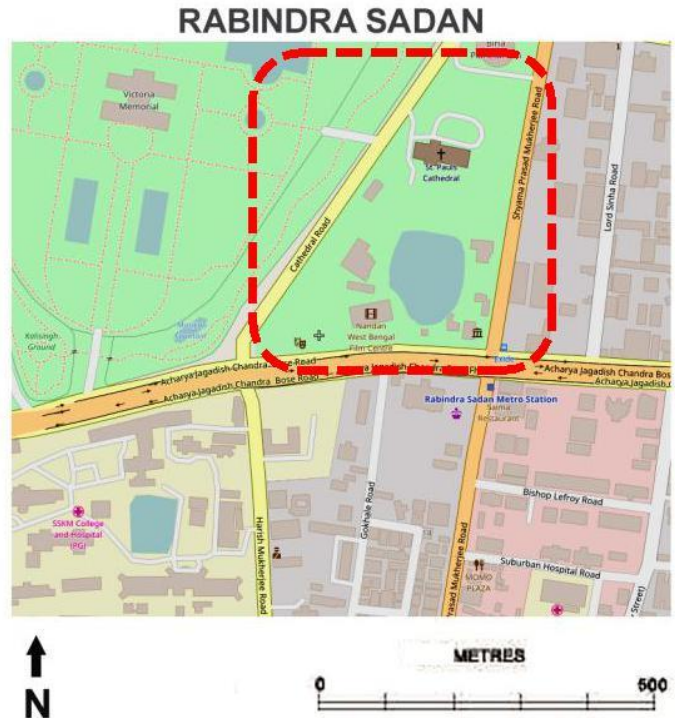

Figure 16. Location map of Rabindra sadan

\section{IV.RESULTS AND DISSCUSSION}

The scores given by the experts have been averaged to arrive at final values representing existing level of physical and emotional attributes as well as potential for intervention. These final scores have been used for comparison among the six locations for identification of possible scale and type of intervention for rejuvenation of specific land uses. Since the scores has been ascribed in a five point Likert scale therefore a score higher than 3 is considered to be significant. Tables 2 and 3 compares the locations based on tangible and intangible elements linked with imageability, and Table 4 provides the potential and type of intervention among the six locations.

TABLE II. COMPARISON OF LOCATIONS BASED ON ELEMENTS OF IMAGEABILITY

\begin{tabular}{|c|c|c|c|c|c|c|}
\hline & \multicolumn{3}{|c|}{ Availability of } & \multicolumn{2}{c|}{ Impact of } \\
\cline { 2 - 7 } Location & $\begin{array}{c}\text { Commu } \\
\text {-nity } \\
\text { space }\end{array}$ & $\begin{array}{c}\text { water } \\
\text { body }\end{array}$ & $\begin{array}{c}\text { green } \\
\text { open } \\
\text { space }\end{array}$ & $\begin{array}{c}\text { public } \\
\text { utilities }\end{array}$ & $\begin{array}{c}\text { heritage } \\
\text { structure }\end{array}$ & $\begin{array}{c}\text { local } \\
\text { culture }\end{array}$ \\
\hline Kalighat & 3.1 & $\mathbf{3 . 6}$ & 3.1 & 3.5 & $\mathbf{3 . 9}$ & $\mathbf{3 . 6}$ \\
\hline $\begin{array}{c}\text { Deshapriya } \\
\text { Park }\end{array}$ & 3.3 & 3.3 & 3.8 & 3.9 & 3 & 3.1 \\
\hline $\begin{array}{c}\text { Rabindra } \\
\text { Sarovar }\end{array}$ & 3.3 & $\mathbf{4 . 3}$ & 4.1 & 3.8 & 3.6 & 3.9 \\
\hline $\begin{array}{c}\text { Rabindra } \\
\text { Sadan }\end{array}$ & 3.5 & 3.7 & 3.9 & 3.9 & 3.6 & 3.8 \\
\hline & & & & & & \\
Esplanade & 3.1 & $\mathbf{2 . 6}$ & 3 & 3 & 3.8 & 2.9 \\
\hline $\begin{array}{c}\text { College } \\
\text { Street }\end{array}$ & 3.5 & 3.4 & $\mathbf{3 . 1}$ & 3.4 & 4 & 3.8 \\
\hline
\end{tabular}


Though the Adi Ganga flows beside the Kalighat Area, which has a high religious significance yet extremely polluted condition of the water renders it unsuitable as a location for relaxation. The river bank is not readily accessible neither is it conducive due to the acrid smell surrounding it. The temple precinct area has a pond for taking bath, before worship of the idol, which is also not readily accessible to the public. There is lack of community space and green open space in the area which has been validated by the obtained score. Overall Kalighat has moderate level of public utilities and is mostly used by people for its religious character emphasized by the scores obtained for impact of heritage structure and local culture. Deshapriya park has green open space and public utilities but not enough tree cover or designated space for community participation. It is famous for Durga Puja a festival of four days held annually during which the space experiences average footfall of 5 lakhs per day which causes chaos for the entire centralsouthern part of the city. Rabindra Sarovar is a favorite haunt for urban residents of surrounding areas who love to spent their mornings in the vicinity of lush green vegetation and a beautiful water body. People from different corners of the city also visit this green space for interaction and relaxation.

Rabindra Sadan is a major centre in the city's cultural landscape. It is well designed and well equipped with utilities. Esplanade is an important commercial centre and transportation node of the city and though it is placed next to the major green open space of Kolkata - Maidan, access to organised green space with tree cover and water body is hindered and availability of public utilities is also moderate. College Street lacks public utilities and green open space. Blocking of sidewalk beside major arterial road, by informal book shops causes disruptions in traffic - both pedestrian and vehicular. The design of the built space does not allow visual circulation thus presence of water body is largely unnoticed and community space for interaction goes largely unutilized. Though teemed in heritage of Bengal renaissance and educational activity the area requires a facelift for better interaction.

TABLE III. COMPARISON OF LOCATIONS BASED ON SPATIAL QUALITY SCORES

\begin{tabular}{|c|c|c|c|c|}
\hline \multirow[b]{2}{*}{ Location } & \multicolumn{4}{|c|}{ Quality based on } \\
\hline & $\begin{array}{c}\text { space } \\
\text { design }\end{array}$ & $\begin{array}{c}\text { emotional } \\
\text { connection }\end{array}$ & $\begin{array}{c}\text { visual } \\
\text { appeal }\end{array}$ & $\begin{array}{c}\text { average } \\
\text { score }\end{array}$ \\
\hline Kalighat & 3.3 & 3.8 & 1.8 & 3 \\
\hline $\begin{array}{c}\text { Deshapriya } \\
\text { Park } \\
\end{array}$ & 3.6 & 3.1 & 2.7 & 3.1 \\
\hline $\begin{array}{c}\text { Rabindra } \\
\text { Sarovar }\end{array}$ & 3.9 & 3.8 & 3.3 & 3.7 \\
\hline $\begin{array}{l}\text { Rabindra } \\
\text { Sadan }\end{array}$ & 3.8 & 3.7 & 3.7 & 3.7 \\
\hline Esplanade & 2.9 & 3.3 & 2.5 & 2.9 \\
\hline College Street & 3.4 & 3.9 & 2.8 & 3.4 \\
\hline
\end{tabular}

Rabindra Sarovar and Rabindra Sadan emerge as locations having best overall scores representing attractiveness to urban dwellers as proper interaction space. Visual appeal of the locations mirrors the general imageability, which places Kalighat as the least attractive place to visit, though the emotional connection to the space is high. Since none of the scores have gone beyond 4 it indicates the necessity for rejuvenation.

Average scores obtained for different modes of intervention across the six locations outlines no clear winner as there is no significant difference between scores 3.5, 3.6 and 3.7. The slight difference between scores for intervention through public utilities and other means is also not significant to be declared for the whole of Kolkata. However, scores for individual locations depicts better choice for intervention. Each location has different character and set of challenges, hence calls for specific intervention.

TABLE IV. COMPARISON OF LOCATIONS BASED ON SCOPE OF INTERVENTION

\begin{tabular}{|c|c|c|c|c|}
\hline \multirow{2}{*}{ Location } & \multicolumn{4}{|c|}{ Intervention potentiality based on } \\
\cline { 2 - 5 } & $\begin{array}{c}\text { space } \\
\text { design }\end{array}$ & $\begin{array}{c}\text { public } \\
\text { utilities }\end{array}$ & $\begin{array}{c}\text { installation } \\
\text { art }\end{array}$ & $\begin{array}{c}\text { Art } \\
\text { performance }\end{array}$ \\
\hline Kalighat & 3.4 & 2.4 & $\mathbf{3 . 6}$ & $\mathbf{3 . 6}$ \\
\hline $\begin{array}{c}\text { Deshapriya } \\
\text { Park }\end{array}$ & $\mathbf{3 . 5}$ & 3.2 & $\mathbf{3 . 5}$ & 3.3 \\
\hline $\begin{array}{c}\text { Rabindra } \\
\text { Sarovar }\end{array}$ & 3.4 & 3.5 & 3.3 & $\mathbf{3 . 9}$ \\
\hline $\begin{array}{c}\text { Rabindra } \\
\text { Sadan }\end{array}$ & $\mathbf{4 . 1}$ & 3.4 & $\mathbf{3 . 7}$ & $\mathbf{3 . 9}$ \\
\hline Esplanade & $\mathbf{3 . 8}$ & $\mathbf{4 . 1}$ & $\mathbf{3 . 7}$ & 3.2 \\
\hline College & & & & 3.6 \\
\hline Street & $\mathbf{3 . 8}$ & 3.4 & 3.3 & 3.4 \\
\hline Average & $\mathbf{3 . 7}$ & $\mathbf{3 . 3}$ & & $\mathbf{3 . 5}$ \\
\hline
\end{tabular}

Kalighat area can benefit most from techno-art interventions considering less spatial availability for physical design interventions. Rabindra Sarovar and Rabindra Sadan require art performances considering they are the most attractive locations as per Table 3. However, the scope of intervention through space design, installation art is also significant for Rabindra Sadan which has organised space for art performances. The obtained scores for Rabindra Sadan may be interpreted as calling for temporary structures that may be replaced to introduce more variety. Esplanade requires better physical design offering more accessible green open space and water body, public utilities as well as installation art. College street mainly requires intervention through space design. In all locations there are moderate to high scope of intervention through art installations, art performances as well as space design for creating more acceptable public spaces.

The six locations in Kolkata portray that in a developing nation context, urban spaces in

1. Locations having majorly commercial activity require better physical space design

2. Locations beside major transportation corridors require better public utilities

3. Locations having majorly residential -mixed 
residential land use require installation art and art

performances

\section{CONCLUSSION}

Analysis of imageability of all (20) urban spaces are not possible to present in a single presentational paper. Therefore, the given data set of six representational spaces were analyzed to come up at an imageability assessment. The data sheet manifest lower scores representing imageability of the selected urban nodes than expected, hence, pinpoint higher potential for intervention by art and design solutions.

Gradual degradation of the physical attributes as lack of community space, open spaces, water body, and public facilities have acted as a catalyst to lower the quality of stakeholders' experience. Thus possibility for art and design rejuvenation by implementing public design projects, art installations, and performance art has grown upto 4.1 in terms of space design and public utilities in Esplanade and Rabindra sadan area followed by College Street and Deshapriya park area. Thus, the analysis and calculation shows the extent of techno-art driven design solution aided to alter the imageability and physical experience of urban spaces.

Current imageability were assessed and interventions are actually prescribed based on the specific land-use of those particular spaces. Thus, trying to reuse the solutions to the other spaces with the same land-use pattern. To arrive at the more streamlined applications of the techno-art based solutions and its applications small patterns of land-use shifting and alteration over the day and the year needs to be considered, because, in the Indian set up most of the old cities (Specifically in the case of Kolkata) almost all the locations are all serving a mixed land-use format. Therefore each areas are unique in terms of its urban problems and therefore solutions. Hence, each case studies can be replicated to the areas following the same landuse pattern, but including its own character-specific potential for intervention of art and technology.

\section{ACKNOWLEDGMENT}

This research is majorly based on the expert's opinion survey on the spatio-visual analysis of the Imageability of urban nodes. Urban experts and scholars from different universities have helped me with their views. Thus, for guiding me with their valuable opinions, I would like to thank the experts from IIT Kharagpur and Rabindra Bharati University, Kolkata.

\section{REFERENCES}

[1] K. Lynch, The Image of the City. Cambridge: The MIT Press, 1960.

[2] G. C. C. Douglas,Do-It-Yourself Urban Design: The Social Practice of Informal "Improvement" Through Unauthorized Alteration. City \& Community, March 2014 doi: 10.1111/cico.12029

[3] K. Lynch. The Image of the City. Cambridge: The MIT Press, 1960.

[4] Imageability, Retrieved from http://shodhganga.inflibnet.ac.in/bitstream/10603/9571/38/11_chapter\% 202.pdf

[5] J. Armstrong, The Contested Gallery: Street Art, Ethnography and the Search for Urban Understandings, 2005.

[6] American Planning Association, The role of the arts and culture in planning practice; 205 N. Michigan Ave., Suite 1200, Chicago, IL 606015927, retrieved from www.planning.org

[7] [1] Ibid; Page no.9

[8] Ed. M. Larice, E. Macdonal, The Urban Design Reader, $2^{\text {nd }}$ Edition, Routledge, May-2013 
Tanima Bhattacharya ( $1^{\text {st }}$ author $)$ :

Tanima Bhattacharya is a research scholar, pursuing

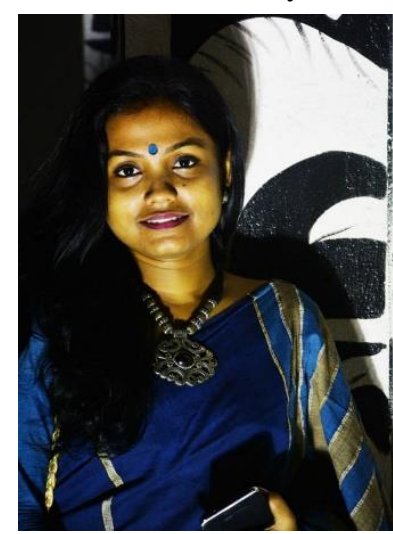
her Ph.D. from School of Infrastructure Design and Management, IIT Kharagpur. She is doing her Ph.D. on 'Implementation of Techno-Art Elements in Augmentation of Urban space Design'.

Tanima has successfully completed her Masters (M.F.A) in History of Art from Kalavaban, Santiniketan. She was awarded the position of First class first in M.F.A in the year 2014. She has graduated from Department of Art History of Rabindra Bharati University in the year 2012 and secured the highest marks. She has completed her English honors from University of Calcutta in the year 2008.

\section{Dr. Ankhi Banerjee ( $2^{\text {nd }}$ author):}

Dr. Ankhi Banerjee is an Architect by profession who completed post-graduation in Urban Design. She did her Ph.D. on 'Assessment of Housing Affordability Inclusive of Variations in Infrastructure Development Within a Metropolis' in 2015. Her area of academic and research interest includes Housing, Social Infrastructure, Livability, Community Planning, Building services and History of Architecture.

Prof. Joy Sen ( $3^{\text {rd }}$ author):

Dr. Joy Sen is a Professor of the Department of Architecture and Regional Planning, Indian Institute of

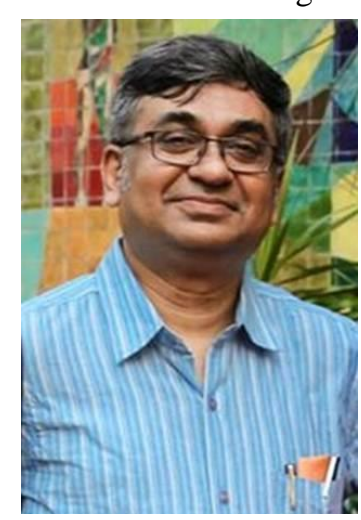
Technology, Kharagpur, West Bengal, India. He is currently Head of Ranbir and Chitra Gupta School of Infrastructure and Design, IIT Kharagpur (2014 2017). His areas of research are Community and Regional Planning Analyses \& Programming and Architecture and Planning related Heritage Studies \& Documentation. $\mathrm{He}$ has a long working experience with the various

Environmental Design programs under DFID Government of the United Kingdom (1995-96) and ISU-UNDP program (1987-89) and IR3S (2011-12) in the University of Tokyo, Japan. He is the recipient of the NCERT/ AISSE Gold Medal for highest marks in social Sciences in All-India level; the Institute silver medal for Highest Aggregate in Bachelors of Architecture, IIT Kharagpur; and best post graduate thesis award from Iowa State University, Ames, Iowa, USA. 